4

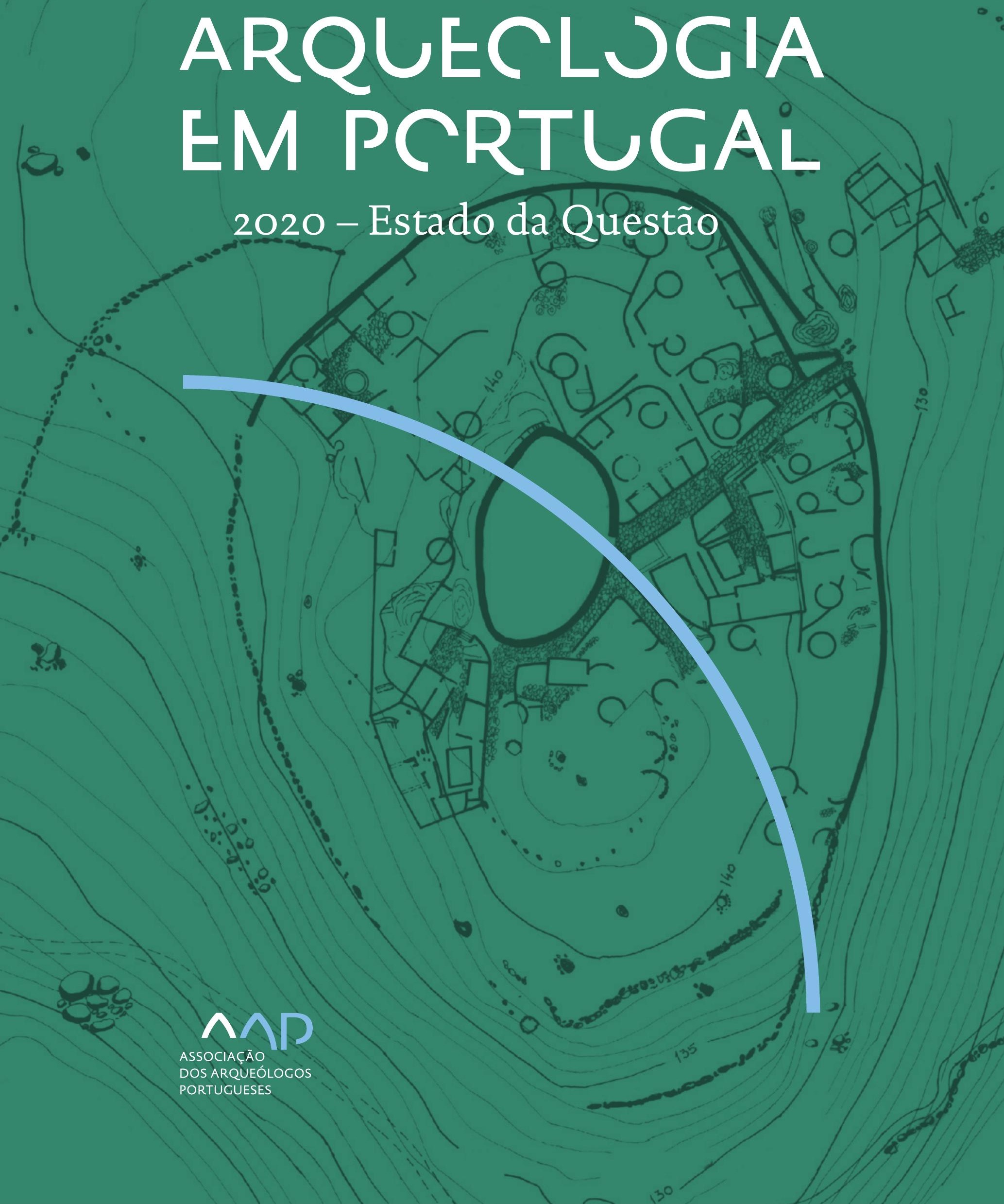


Coordenação editorial: José Morais Arnaud, César Neves e Andrea Martins Design gráfico: Flatland Design

AAP - ISBN: 978-972-9451-89-8

CITCEM - ISBN: 978-989-8970-25-1

Associação dos Arqueólogos Portugueses e CITCEM

Lisboa, 2020

O conteúdo dos artigos é da inteira responsabilidade dos autores. Sendo assim a Associação dos Arqueólogos Portugueses declina qualquer responsabilidade por eventuais equívocos ou questões de ordem ética e legal.

Desenho de capa:

Planta do castro de Monte Mozinho (Museu Municipal de Penafiel).

\section{$\hat{\wedge} \mathrm{P}$}

DOS ARQUEÓLOGOS PORTUGUESES

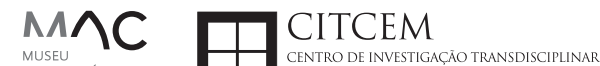
MUSEU
ARQUELLÓGICO
DO CARMO
U.PORTO

FLUP FACULDADE DE LETRAS
UNIVERSIDADE DO PORTO

Apoio

EC para a Ciência 


\section{Índice}

15 Prefácio

José Morais Arnaud

\section{Historiografia e Teoria}

17 Território, comunidade, memória e emoção: a contribuição da história da arqueologia (algumas primeiras e breves reflexões)

Ana Cristina Martins

25 Como descolonizar a arqueologia portuguesa?

Rui Gomes Coelho

41 Arqueologia e Modernidade: uma revisitação pessoal e breve de alguns aspetos da obra homónima de Julian Thomas de 2004

Vítor Oliveira Jorge

57 Dados para a História das Mulheres na Arqueologia portuguesa, dos finais do século XIX aos inícios do século XX: números, nomes e tabelas

Filipa Dimas / Mariana Diniz

73 Retractos da arqueologia portuguesa na imprensa: (in)visibilidades no feminino

Catarina Costeira / Elsa Luís

85 Arqueologia e Arqueólogos no Norte de Portugal Jacinta Bugalhão

101 Vieira Guimarães (1864-1939) e a arqueologia em Tomar: uma abordagem sobre o território e as gentes

João Amendoeira Peixoto / Ana Cristina Martins

115 Os memoráveis? A arqueologia algarvia na imprensa nacional e regional na presente centúria (2001-2019): características, visões do(s) passado(s) e a arqueologia

enquanto marca

Frederico Agosto / João Silva

129 A Evolução da Arqueologia Urbana e a Valorização Patrimonial no Barlavento Algarvio: Os casos de Portimão e Silves

Artur Mateus / Diogo Varandas / Rafael Boavida

\section{Gestão, Valorização e Salvaguarda do Património}

145 O Caderno Reivindicativo e as condições de trabalho em Arqueologia Miguel Rocha / Liliana Matias Carvalho / Regis Barbosa / Mauro Correia / Sara Simões / Jacinta Bugalhão / Sara Brito / Liliana Veríssimo Carvalho / Richard Peace / Pedro Peça / Cézer Santos

155 Os Estudos de Impacte Patrimonial como elemento para uma estratégia sustentável de minimização de impactes no âmbito de reconversões agrícolas Tiago do Pereiro

165 Salvaguarda de Património arqueológico em operações florestais: gestão e sensibilização Filipa Bragança / Gertrudes Zambujo / Sandra Lourenço / Belém Paiva / Carlos Banha / Frederico Tatá Regala / Helena Moura / Jacinta Bugalhão / João Marques / José Correia / Pedro Faria / Samuel Melro

179 Os valores do Património: uma investigação sobre os Sítios Pré-históricos de Arte Rupestre do Vale do Rio Côa e de Siega Verde José Paulo Francisco 
189 Conjugando recursos arqueológicos e naturais para potenciar as visitas ao Geoparque Litoral de Viana do Castelo (Noroeste de Portugal)

Hugo A. Sampaio / Ana M.S. Bettencourt / Susana Marinho / Ricardo Carvalhido

203 Áreas de Potencial Arqueológico na Região do Médio Tejo: Modelo Espacial Preditivo Rita Ferreira Anastácio / Ana Filipa Martins / Luiz Oosterbeek

223 Património Arqueológico e Gestão Territorial: O contributo da Arqueologia para a revisão do PDM de Avis

Ana Cristina Ribeiro

237 A coleção arqueológica do extinto Museu Municipal do Porto - Origens, Percursos e Estudos

Sónia Couto

251 Valpaços - uma nova carta arqueológica

Pedro Pereira / Maria de Fátima Casares Machado

263 Arqueologia na Cidade de Peniche

Adriano Constantino / Luís Rendeiro

273 Arqueologia Urbana: a cidade de Lagos como caso de Estudo Cátia Neto

285 Estratégias de promoção do património cultural subaquático nos Açores. O caso da ilha do Faial

José Luís Neto / José Bettencourt / Luís Borges / Pedro Parreira

297 Carta Arqueológica da Cidade Velha: Uma primeira abordagem

Jaylson Monteiro / Nireide Tavares / Sara da Veiga / Claudino Ramos / Edson Brito /

Carlos Carvalho / Francisco Moreira / Adalberto Tavares

311 Antropologia Virtual: novas metodologias para a análise morfológica e funcional Ricardo Miguel Godinho / Célia Gonçalves

\section{Didáctica da Arqueologia}

327 Como os projetos de Arqueologia podem contribuir para uma comunidade culturalmente mais consciente Alexandra Figueiredo / Claúdio Monteiro / Adolfo Silveira / Ricardo Lopes

337 Educação Patrimonial - Um cidadão esclarecido é um cidadão ativo! Ana Paula Almeida

351 A aproximação da Arqueologia à sala de aula: um caso de estudo no $3^{\circ}$ ciclo do Ensino Básico Luís Serrão Gil

363 Arqueologia 3.o - Pensar e comunicar a Arqueologia para um futuro sustentável Mónica Rolo

377 “Conversa de Arqueólogos" - Divulgar a Arqueologia em tempos de Pandemia Diogo Teixeira Dias

389 Escola Profissional de Arqueologia: desafios e oportunidades Susana Nunes / Dulcineia Pinto / Júlia Silva / Ana Mascarenhas

399 Os Museus de Arqueologia e os Jovens: a oferta educativa para o público adolescente Beatriz Correia Barata / Leonor Medeiros

411 O museu universitário como mediador entre a ciência e a sociedade: o exemplo da secção de arqueologia no Museu de História Natural e da Ciência da Universidade do Porto (MHNC-UP)

Rita Gaspar 
421 Museu de Lanifícios: Real Fábrica de Panos. Atividades no âmbito da Arqueologia Beatriz Correia Barata / Rita Salvado

427 Arqueologia Pública e o caso da localidade da Mata (Torres Novas) Cláudia Manso / Ana Rita Ferreira / Cristiana Ferreira / Vanessa Cardoso Antunes

431 Do sítio arqueológico ao museu: um percurso (também) didático Lídia Fernandes

447 Estão todos convidados para a Festa! E para dançar também... O projecto do Serviço Educativo do Museu Arqueológico do Carmo na $5^{\underline{a}}$ Edição da Festa da Arqueologia Rita Pires dos Santos

459 O “Clã de Carenque”, um projeto didático de arqueologia Eduardo Gonzalez Rocha

469 Mediação cultural: peixe que puxa carroça nas Ruínas Romanas de Troia Inês Vaz Pinto / Ana Patrícia Magalhães / Patrícia Brum / Filipa Santos

481 Didática Arqueológica, experiências do Projeto Mértola Vila Museu Maria de Fátima Palma / Clara Rodrigues / Susana Gómez / Lígia Rafael

\section{Arte Rupestre}

497 Os inventários de arte rupestre em Portugal Mila Simões de Abreu

513 O projeto FIRST-ART - conservação, documentação e gestão das primeiras manifestações de arte rupestre no Sudoeste da Península Ibérica: as grutas do Escoural e Maltravieso Sara Garcês / Hipólito Collado / José Julio García Arranz / Luiz Oosterbeek / António Carlos Silva / Pierluigi Rosina / Hugo Gomes / Anabela Borralheiro Pereira / George Nash / Esmeralda Gomes / Nelson Almeida / Carlos Carpetudo

523 Trabalhos de documentação de arte paleolítica realizados no âmbito do projeto PalæoCôa André Tomás Santos / António Fernando Barbosa / Luís Luís / Marcelo Silvestre / Thierry Aubry

537 Imagens fantasmagóricas, silhuetas elusivas: as figuras humanas na arte do Paleolítico Superior da região do Côa Mário Reis

$55^{1}$ Os motivos zoomórficos representados nas placas de tear de Vila Nova de São Pedro (Azambuja, Portugal) Andrea Martins / César Neves / José M. Arnaud / Mariana Diniz

571 Arte Rupestre do Monte de Góios (Lanhelas, Caminha). Síntese dos resultados dos trabalhos efectuados em 2007-2009 Mário Varela Gomes

599 Gravuras rupestres de barquiformes no Monte de S. Romão, Guimarães, Noroeste de Portugal Daniela Cardoso

613 Círculos segmentados gravados na Bacia do Rio Lima (Noroeste de Portugal): contributos para o seu estudo Diogo Marinho / Ana M.S. Bettencourt / Hugo Aluai Sampaio

631 Equídeos gravados no curso inferior do Rio Mouro, Monção (NW Portugal). Análise preliminar Coutinho, L.M. / Bettencourt, A.M.S / Sampaio, Hugo A.S

645 Paletas na Arte Rupestre do Noroeste de Portugal. Inventário preliminar Bruna Sousa Afonso / Ana M. S. Bettencourt / Hugo A. Sampaio 


\section{Pré-História}

661 O projeto Miño/Minho: balanço de quatro anos de trabalhos arqueológicos Sérgio Monteiro-Rodrigues / João Pedro Cunha-Ribeiro / Eduardo Méndez-Quintas / Carlos Ferreira / Pedro Xavier / José Meireles / Alberto Gomes / Manuel Santonja / Alfredo Pérez-González

677 A ocupação paleolítica da margem esquerda do Baixo Minho: a indústria lítica do sítio de Pedreiras 2 (Monção, Portugal) e a sua integração no contexto regional Carlos Ferreira / João Pedro Cunha-Ribeiro / Sérgio Monteiro-Rodrigues / Eduardo Méndez-Quintas / Pedro Xavier / José Meireles / Alberto Gomes / Manuel Santonja / Alfredo Pérez-González

693 O sítio acheulense do Plistocénico médio da Gruta da Aroeira Joan Daura / Montserrat Sanz / Filipa Rodrigues / Pedro Souto / João Zilhão

703 As sociedades neandertais no Barlavento algarvio: modelos preditivos com recurso aos SIG

Daniela Maio

715 A utilização de quartzo durante o Paleolítico Superior no território dos vales dos rios Vouga e Côa

Cristina Gameiro / Thierry Aubry / Bárbara Costa / Sérgio Gomes / Luís Luís / Carmen Manzano / André Tomás Santos

733 Uma perspetiva diacrónica da ocupação do concheiro do Cabeço da Amoreira (Muge, Portugal) a partir da tecnologia lítica Joana Belmiro / João Cascalheira / Célia Gonçalves

745 Novos dados sobre a Pré-história Antiga no concelho de Palmela. A intervenção arqueológica no sítio do Poceirão I

Michelle Teixeira Santos

757 Problemas em torno de Datas Absolutas Pré-Históricas no Norte do Alentejo Jorge de Oliveira

771 Povoamento pré-histórico nas áreas montanhosas do NO de Portugal: o Abrigo 1 de Vale de Cerdeira Pedro Xavier / José Meireles / Carlos Alves

783 Apreciação do povoamento do Neolítico Inicial na Baixa Bacia do Douro. A Lavra I (Serra da Aboboreira) como caso de estudo Maria de Jesus Sanches

797 O Processo de Neolitização na Plataforma do Mondego: os dados do Sector C do Outeiro dos Castelos de Beijós (Carregal do Sal)

João Carlos de Senna-Martinez / José Manuel Quintã Ventura / Andreia Carvalho / Cíntia Maurício

823 Novos trabalhos na Lapa da Bugalheira (Almonda, Torres Novas) Filipa Rodrigues / Pedro Souto / Artur Ferreira / Alexandre Varanda / Luís Gomes / Helena Gomes / João Zilhão

837 A pedra polida e afeiçoada do sítio do Neolítico médio da Moita do Ourives (Benavente, Portugal)

César Neves

857 Casal do Outeiro (Encarnação, Mafra): novos contributos para o conhecimento do povoamento do Neolítico final na Península de Lisboa.

Cátia Delicado / Carlos Maneira e Costa / Marta Miranda / Ana Catarina Sousa

873 Stresse infantil, morbilidade e mortalidade no sítio arqueológico do Neolítico Final/ Calcolítico ( $4^{\circ}$ e $3^{\circ}$ milénio a.C.) do Monte do Carrascal 2 (Ferreira do Alentejo, Beja) Liliana Matias de Carvalho / Sofia N. Wasterlain 
885 Come together: O Conjunto Megalítico das Motas (Monção, Viana do Castelo) e as expressões Campaniformes do Alto Minho Ana Catarina Basílio / Rui Ramos

899 Trabalhos arqueológicos no sítio Calcolítico da Pedreira do Poio Carla Magalhães / João Muralha / Mário Reis / António Batarda Fernandes

913 O sítio arqueológico de Castanheiro do Vento. Da arquitectura do sítio à arquitectura de um território João Muralha Cardoso

925 Estudo zooarqueológico das faunas do Calcolítico final de Vila Nova de São Pedro (Azambuja, Portugal): Campanhas de 2017 e 2018 Cleia Detry / Ana Catarina Francisco / Mariana Diniz / Andrea Martins / César Neves / José Morais Arnaud

943 As faunas depositadas no Museu Arqueológico do Carmo provenientes de Vila Nova de São Pedro (Azambuja): as campanhas de 1937 a 1967 Ana Catarina Francisco / Cleia Detry / César Neves / Andrea Martins / Mariana Diniz / José Morais Arnaud

959 Análise funcional de material lítico em sílex do castro de Vila Nova de S. Pedro (Azambuja, Portugal): uma primeira abordagem Rafael Lima

971 O recinto da Folha do Ouro 1 (Serpa) no contexto dos recintos de fossos calcolíticos alentejanos

António Carlos Valera / Tiago do Pereiro / Pedro Valério / António M. Monge Soares

\section{Proto-História}

987 Produção de sal marinho na Idade do Bronze do noroeste Português. Alguns dados para uma reflexão

Ana M. S. Bettencourt / Sara Luz / Nuno Oliveira / Pedro P. Simões / Maria Isabel C. Alves / Emílio Abad-Vidal

1001 A estátua-menir do Pedrão ou de São Bartolomeu do Mar (Esposende, noroeste de Portugal) no contexto arqueológico da fachada costeira de entre os rios Neiva e Cávado Ana M. S. Bettencourt / Manuel Santos-Estévez / Pedro Pimenta Simões / Luís Gonçalves

1015 O Castro do Muro (Vandoma/Baltar, Paredes) - notas para uma biografia de ocupação da Idade do Bronze à Idade Média

Maria Antónia D. Silva / Ana M. S. Bettencourt / António Manuel S. P. Silva / Natália Félix

1031 Do Bronze Final à Idade Média - continuidades e hiatos na ocupação de Povoados em Oliveira de Azeméis João Tiago Tavares / Adriaan de Man

1041 As faunas do final da Idade do Bronze no Sul de Portugal: leituras desde o Outeiro do Circo (Beja)

Nelson J. Almeida / Íris Dias / Cleia Detry / Eduardo Porfírio / Miguel Serra

1055 A Espada do Monte das Oliveiras (Serpa) - uma arma do Bronze Pleno do Sudoeste Rui M. G. Monge Soares / Pedro Valério / Mariana Nabais / António M. Monge Soares

1065 São Julião da Branca (Albergaria-a-Velha) - Investigação e valorização de um povoado do Bronze Final

António Manuel S. P. Silva / Paulo A. P. Lemos / Sara Almeida e Silva / Edite Martins de Sá

1083 Do castro de S. João ao Mosteiro de Santa Clara: notícia de uma intervenção arqueológica, em Vila do Conde Rui Pinheiro 
1095 O castro de Ovil (Espinho), um quarto de século de investigação - resultados e questões em aberto

Jorge Fernando Salvador / António Manuel S. P. Silva

1111 O Castro de Salreu (Estarreja), um povoado proto-histórico no litoral do Entre Douro e Vouga

Sara Almeida e Silva / António Manuel S. P. Silva / Paulo A. P. Lemos / Edite Martins de Sá

1127 Castro de Nossa Senhora das Necessidades (Sernancelhe): uma primeira análise artefactual Telma Susana O. Ribeiro

${ }_{1141}$ A cividade de Bagunte. O estado atual da investigação Pedro Brochado de Almeida

1153 Zoomorfos na cerâmica da Idade do Ferro no NW Peninsular: inventário, cronologias e significado Nuno Oliveira / Cristina Seoane

1163 Vasos gregos em Portugal: diferentes maneiras de contar a história do intercâmbio cultural na Idade do Ferro

Daniela Ferreira

1175 Os exotica da necrópole da Idade do Ferro do Olival do Senhor dos Mártires (Alcácer do Sal) no seu contexto regional

Francisco B. Gomes

\section{Antiguidade Clássica e Tardia}

1191 O uso de madeira como combustível no sítio da Quinta de Crestelos (Baixo Sabor): da Idade do Ferro à Romanização Filipe Vaz / João Tereso / Sérgio Simões Pereira / José Sastre / Javier Larrazabal Galarza / Susana Cosme / José António Pereira / Israel Espi

1207 Cultivos de Época Romana no Baixo Sabor: continuidade em tempos de mudança? João Pedro Tereso / Sérgio Simões Pereira / Filipe Santos / Luís Seabra / Filipe Vaz

1221 A casa romana na Hispânia: aplicação dos modelos itálicos nas províncias ibéricas Fernanda Magalhães / Diego Machado / Manuela Martins

1235 As pinturas murais romanas da Rua General Sousa Machado, n. ${ }^{5}$ 1, Chaves José Carvalho

1243 Trás do Castelo (Vale de Mir, Pegarinhos, Alijó) - Uma exploração agrícola romana do Douro

Tony Silvino / Pedro Pereira

1255 A sequência de ocupação no quadrante sudeste de Bracara Augusta: as transformações de uma unidade doméstica Lara Fernandes / Manuela Martins

1263 Os Mosaicos com decoração geométrica e geométrico-vegetalista dos sítios arqueológicos da área do Conuentus Bracaraugustanus. Novas abordagens quanto à conservação, restauro, decoração e datação Maria de Fátima Abraços / Licínia Wrench

1277 “Casa Romana” do Castro de São Domingos (Cristelos, Lousada): Escavação, Estudo e Musealização Paulo André de P. Lemos

1291 A arqueobotânica no Castro de Guifões (Matosinhos, Noroeste de Portugal): O primeiro estudo carpológico

Luís Seabra / Andreia Arezes / Catarina Magalhães / José Varela / João Pedro Tereso 
1305 Um Horreum Augustano na Foz do Douro (Monte do Castelo de Gaia, Vila Nova de Gaia) Rui Ramos

1311 Ponderais romanos na Lusitânia: padrões, formas, materiais e contextos de utilização Diego Barrios Rodríguez

1323 Um almofariz centro-itálico na foz do Mondego

Marco Penajoia

1335 Estruturas romanas de Carnide - Lisboa Luísa Batalha / Mário Monteiro / Guilherme Cardoso

1347 O contexto funerário do sector da "necrópole NO" da Rua das Portas de S. Antão (Lisboa): o espaço, os artefactos, os indivíduos e a sua interconectividade na interpretação do passado Sílvia Loja, José Carlos Quaresma, Nelson Cabaço, Marina Lourenço, Sílvia Casimiro, Rodrigo Banha da Silva, Francisca Alves-Cardoso

${ }_{1361}$ Povoamento em época Romana na Amadora - resultados de um projeto pluridisciplinar Gisela Encarnação / Vanessa Dias

1371 A Arquitectura Residencial em Mirobriga (Santiago do Cacém): contributo a partir de um estudo de caso Filipe Sousa / Catarina Felício

${ }_{1385}$ O fim do ciclo. Saneamento e gestão de resíduos nos edifícios termais de Mirobriga (Santiago do Cacém)

Catarina Felício / Filipe Sousa

1399 Balsa, Topografia e Urbanismo de uma Cidade Portuária Vítor Silva Dias / João Pedro Bernardes / Celso Candeias / Cristina Tété Garcia

1413 No Largo das Mouras Velhas em Faro (2017): novas evidências da necrópole norte de Ossonoba e da sua ocupação medieval Ricardo Costeira da Silva / Paulo Botelho / Fernando Santos / Liliana Nunes

1429 Instrumentos de pesca recuperados numa fábrica de salga em Ossonoba (Faro) Inês Rasteiro / Ricardo Costeira da Silva / Paulo Botelho

1439 A Necrópole Romana do Eirô, Duas Igrejas (Penafiel): intervenção arqueológica de 2016 Laura Sousa / Teresa Soeiro

1457 Ritual, descarte ou afetividade? A presença de Canis lupus familiaris na Necrópole Noroeste de Olisipo (Lisboa)

Beatriz Calapez Santos / Sofia Simões Pereira / Rodrigo Banha da Silva / Sílvia Casimiro / Cleia Detry / Francisca Alves Cardoso

1467 Dinâmicas económicas em Bracara na Antiguidade Tardia Diego Machado / Manuela Martins / Fernanda Magalhães / Natália Botica

1479 Cerâmicas e Vidros da Antiguidade Tardia do Edifício sob a Igreja do Bom Jesus (Vila Nova de Gaia) Joaquim Filipe Ramos

1493 Novos contributos para a topografia histórica de Mértola no período romano e na Antiguidade Tardia Virgílio Lopes

\section{8. Época Medieval}

1511 Cerâmicas islâmicas no Garb setentrional "português": algumas evidências e incógnitas Constança dos Santos / Helena Catarino / Susana Gómez / Maria José Gonçalves / Isabel Inácio / Gonçalo Lopes / Jacinta Bugalhão / Sandra Cavaco / Jaquelina Covaneiro / Isabel Cristina Fernandes / Ana Sofia Gomes 
1525 Contributo para o conhecimento da cosmética islâmica, em Silves, durante a Idade Média Rosa Varela Gomes

1537 Yábura e o seu território - uma análise histórico-arqueológica de Évora entre os séculos VIII-XII José Rui Santos

1547 A encosta sul do Castelo de Palmela - resultados preliminares da escavação arqueológica Luís Filipe Pereira / Michelle Teixeira Santos

1559 A igreja de São Lourenço (Mouraria, Lisboa): um conjunto de silos e de cerâmica medieval islâmica

Andreia Filipa Moreira Rodrigues

1571 O registo material de movimentações populacionais no Médio Tejo, durante os séculos XII-XIII. Dois casos de "sunken featured buildings", nos concelhos de Cartaxo e Torres Novas Marco Liberato / Helena Santos / Nuno Santos

1585 O nordeste transmontano nos alvores da Idade média. Notas para reflexão Ana Maria da Costa Oliveira

1601 Sepulturas escavadas na rocha do Norte de Portugal e do Vale do Douro: primeiros resultados do Projecto SER-NPVD

Mário Jorge Barroca / César Guedes / Andreia Arezes / Ana Maria Oliveira

1619 "Portucalem Castrum Novum" entre o Mediterrâneo e o Atlântico: o estudo dos materiais cerâmicos alto-medievais do arqueossítio da rua de D. Hugo, nํ. 5 (Porto) João Luís Veloso

1627 A Alta Idade Média na fronteira de Lafões: notas preliminares sobre a Arqueologia no Concelho de Vouzela

Manuel Luís Real / Catarina Tente

1641 Um conjunto cerâmico medieval fora de portas: um breve testemunho aveirense Susana Temudo

${ }_{1651}$ Os Lóios do Porto: uma perspetiva integrada no panorama funerário da Baixa Idade Média à Época Moderna em meios urbanos em Portugal

Ana Lema Seabra

1659 O Caminho Português Interior de Santiago como eixo viário na Idade Média Pedro Azevedo

1665 Morfologia Urbana: Um exercício em torno do Castelo de Ourém André Donas-Botto / Jaqueline Pereira

1677 Intervenção arqueológica na Rua Marquês de Pombal/Largo do Espírito Santo (Bucelas, Loures)

Florbela Estêvão / Nathalie Antunes-Ferreira / Dário Ramos Neves / Inês Lisboa

1691 O Cemitério Medieval do Poço do Borratém e a espacialidade funerária na cidade de Lisboa Inês Belém / Vanessa Filipe / Vasco Noronha Vieira / Sónia Ferro / Rodrigo Banha da Silva

1705 Um Espaço Funerário Conventual do séc. XV em Lisboa: o caso do Convento de São Domingos da Cidade Sérgio Pedroso / Sílvia Casimiro / Rodrigo Banha da Silva / Francisca Alves Cardoso

\section{9. Época Moderna e Contemporânea}

1721 Arqueologia Moderna em Portugal: algumas reflexões críticas em torno da quantificação de conjuntos cerâmicos e suas inferências históricas e antropológicas Rodrigo Banha da Silva / André Bargão / Sara da Cruz Ferreira

1733 Faianças de dois contextos entre os finais do século XVI e XVIII do Palácio dos Condes de Penafiel, Lisboa

Martim Lopes / Tomás Mesquita 
1747 Um perfil de consumo do século XVIII na foz do Tejo: O caso do Mercado da Ribeira, Lisboa Sara da Cruz Ferreira / Rodrigo Banha da Silva / André Bargão

1761 Os Cachimbos dos Séculos XVII e XVIII do Palácio Mesquitela e Convento dos Inglesinhos (Lisboa)

Inês Simão / Marina Pinto / João Pimenta / Sara da Cruz Ferreira / André Bargão / Rodrigo Banha da Silva

1775 "Tomar os fumos da erua que chamão em Portugal erua sancta». Estudo de Cachimbos provenientes da Rua do Terreiro do Trigo, Lisboa

Miguel Martins de Sousa / José Pedro Henriques / Vanessa Galiza Filipe

1787 Cachimbos de Barro Caulínitico da Sé da Cidade Velha (República de Cabo Verde)

Rodrigo Banha da Silva / João Pimenta / Clementino Amaro

1801 Algumas considerações sobre espólio não cerâmico recuperado no Largo de Jesus (Lisboa) Carlos Boavida

1815 Adereços de vidro, dos séculos XVI-XVIII, procedentes do antigo Convento de Santana de Lisboa (anéis, braceletes e contas)

Joana Gonçalves / Rosa Varela Gomes / Mário Varela Gomes

1837 Da ostentação, luxo e poder à simplicidade do uso quotidiano: arqueologia e simbologia de joias e adornos da Idade Moderna Portuguesa Jéssica Iglésias

1849 Os amuletos em Portugal - dos objetos às superstições: o coral vermelho Alexandra Vieira

1865 Cerâmicas de Vila Franca de Xira nos séculos XV e XVI Eva Pires

1879 «Não passa por teu o que me pertence». Marcas de individualização associadas a faianças do Convento de Nossa Senhora de Aracoeli, Alcácer do Sal Catarina Parreira / Íris Fragoso / Miguel Martins de Sousa

1891 Cerâmica de Leiria: alguns focos de produção

Jaqueline Pereira / André Donas-Botto

1901 Os Fornos na Rua da Biquinha, em Óbidos Hugo Silva / Filipe Oliveira

1909 A casa de Pêro Fernandes, contador dos contos de D. Manuel I: o sítio arqueológico da Silha do Alferes, Seixal (século XVI) Mariana Nunes Ferreira

1921 O Alto da Vigia (Sintra) e a vigilância e defesa da costa Alexandre Gonçalves / Sandra Santos

1937 O contexto da torre sineira da Igreja de Santa Maria de Loures Paulo Calaveira / Martim Lopes

1949 A Necrópole do Hospital Militar do Castelo de São Jorge e as práticas funerárias na Lisboa de Época Moderna Susana Henriques / Liliana Matias de Carvalho / Ana Amarante / Sofia N. Wasterlain

1963 SAND - Sarilhos Grandes Entre dois Mundos: o adro da Igreja e a Paleobiologia dos ossos humanos recuperados

Paula Alves Pereira / Roger Lee Jesus / Bruno M. Magalhães

1975 Expansão urbana da vila de Cascais no século XVII e XVIII: a intervenção arqueológica na Rua da Vitória no 15 a 17

Tiago Pereira / Vanessa Filipe

1987 Novos dados para o conhecimento do Urbanismo de Faro em época Moderna Ana Rosa 
1995 Um exemplo de Arqueologia Urbana em Alcoutim: o Antigo Edifício dos CTT Marco Fernandes / Marta Dias / Alexandra Gradim / Virgílio Lopes / Susana Gómez Martínez

2007 Palácio dos Ferrazes (Rua das Flores/Rua da Vitória, Porto): a cocheira de Domingos Oliveira Maia

Francisco Raimundo

2021 As muitas vidas de um edifício urbano: História, Arqueologia e Antropologia no antigo Recreatório Paroquial de Penafiel Helena Bernardo / Jorge Sampaio / Marta Borges

2035 O convento de Nossa Senhora da Esperança de Ponta Delgada: o contributo da arqueologia para o conhecimento de um monumento identitário João Gonçalves Araújo / N’Zinga Oliveira

2047 Arqueologia na ilha do Corvo... em busca da capela de Nossa Senhora do Rosário Tânia Manuel Casimiro / José Luís Neto / Luís Borges / Pedro Parreira

2059 Perdidos à vista da Costa. Trabalhos arqueológicos subaquáticos na Barra do Tejo Jorge Freire / José Bettencourt / Augusto Salgado

2071 Arqueologia marítima em Cabo Verde: enquadramento e primeiros resultados do projecto CONCHA

José Bettencourt / Adilson Dias / Carlos Lima / Christelle Chouzenoux / Cristóvão Fonseca / Dúnia Pereira / Gonçalo Lopes / Inês Coelho / Jaylson Monteiro / José Lima / Maria Eugénia Alves / Patrícia Carvalho / Tiago Silva

2085 Trabalhos arqueológicos na Cidade Velha (Ribeira Grande de Santiago, Cabo Verde): reflexões sobre um projecto de investigação e divulgação patrimonial André Teixeira / Jaylson Monteiro / Mariana Mateus / Nireide Tavares / Cristovão Fonseca / Gonçalo C. Lopes / Joana Bento Torres / Dúnia Pereira / André Bargão / Aurélie Mayer / Bruno Zélie / Carlos Lima / Christelle Chouzenoux / Inês Henriques / Inês Pinto Coelho / José Lima / Patrícia Carvalho / Tiago Silva

2103 A antiga fortificação de Quelba / Khor Kalba (E.A.U.). Resultados de quatro campanhas de escavações, problemáticas e perspectivas futuras Rui Carita / Rosa Varela Gomes / Mário Varela Gomes / Kamyar Kamyad

2123 Colónias para homens novos: arqueologia da colonização agrária fascista no noroeste ibérico Xurxo Ayán Vila / José Mạ . Señorán Martín 


\title{
O FIM DO CICLO. SANEAMENTO E GESTÃO DE RESÍDUOS NOS EDIFÍCIOS TERMAIS DE MIROBRIGA (SANTIAGO DO CACÉM)
}

\author{
Catarina Felício ${ }^{1}$, Filipe Sousa ${ }^{2}$
}

\begin{abstract}
RESUMO
Os edifícios termais de Mirobriga encontram-se localizados no seu ponto mais baixo, num vale conformado pelas colinas onde se desenvolvia o núcleo urbano. O seu bom estado de conservação permitiu a análise detalhada de um dos sistemas fundamentais no funcionamento de um edifício termal: o sistema de escoamento. Dedicados à limpeza e cuidado do corpo, os edifícios termais são, paradoxalmente, grandes focos de poluição, gerando vastas quantidades de efluentes.

O estudo do sistema de escoamento e resíduos gerados permitiu colocar esta questão em evidência, contribuindo para uma imagem mais clara da atmosfera e salubridade em torno e no interior destes espaços de lazer e socialização.
\end{abstract}

Palavras-chave: Gestão de resíduos, Poluição urbana, Balnea, Cloaca, Latrina.

\begin{abstract}
The bath buildings identified in Mirobriga were built a low area, surrounded by several hills. Both are well preserved allowing for a detailed analysis of a fundamental part of its functioning: the sewage system.

Despite being dedicated to bathing and body care, bath buildings are, none the less, responsible for a great amount of pollution, due to the vast volume of wastewater generated.

The analysis of the drainage/sewage system and of the overall waste produced within these buildings has brought some light to the subject as well as giving a clearer picture of what could have been overall atmosphere and salubrity in and around these places of leisure and socialization.

Keywords: Waste management, Urban pollution, Balnea, Cloaca, Latrine.
\end{abstract}

\section{INTRODUÇÃO}

Embora a identificação de uma cidade romana no Castelo Velho de Santiago do Cacém remonte ao século XVI, suscitando interesse de diversas personalidades ao longo dos séculos que se seguiram (Barata e Vale 2010, p. 12-15), seria a descoberta de um caldarium no fundo de um pequeno vale a marcar o início da sua escavação sistemática (por exemplo Silva 1944).

O local seria alvo de escavação extensiva em vários momentos das décadas de 1940 a 1970, sendo o primeiro edifício identificado apelidado de Termas Oeste, após a descoberta de um segundo edifício termal (Termas Este) situado paredes-meias (Silva 1944; Almeida 1964).

O primeiro estudo completo dos edifícios seria publicado em 1988 (Biers), sendo estes posteriormente incluídos no trabalho dedicado aos diversos edifícios termais urbanos da Lusitania (Reis 2014), bem como no estudo do sistema de saneamento da cidade de Mirobriga (Felício 2019), trabalho de um

\footnotetext{
1. (FCSH-UNL); catarina.m.felicio@gmail.com

2. (FCSH-UNL); filipe.alb.sousa@gmail.com
} 
dos signatários que serve de base para o presente artigo, que actualiza e aprofunda o estudo anteriormente efectuado.

As designações aqui utilizadas para os diferentes elementos do sistema de escoamento dos edifícios termais de Mirobriga, aqui apresentados de forma sintética, correspondem ao inventário efectuado para esse estudo, onde são apresentadas as características e dimensões de cada um de forma mais pormenorizada.

\section{O CICLO DA ÁGUA NOS EDIFÍCIOS TERMAIS DE ÉPOCA ROMANA}

De entre os diversos edifícios e recintos de lazer, os edifícios afectos a actividades balneares destacam-se não só pela «modernidade» que o conceito a elas subjacente pode suscitar, mas, sobretudo pela forma como o seu correcto funcionamento pressupõe a existência de dois complexos sistemas funcionais que se interligam: o sistema de calefacção e o sistema hídrico. Sendo o último o mais complexo e aquele que mais condicionantes impõe aquando da escolha de um local para a construção de um novo edifício termal, não fosse a água o «elemento que dá sentido à arquitectura termal» (Acero 2018b).

A escolha de uma localização para um edifício balnear, teria como condicionante a disponibilidade e aprovisionamento de água, existindo, para esse efeito, várias possibilidades: construção de cisternas para colecção e armazenamento de águas pluviais; existência de nascentes no local ou construção de poços ou minas de água; utilização das águas de rios ou outros cursos de água; ou construção de aquedutos para o transporte de água a partir de fontes geograficamente distantes (Manderscheid $2000 \mathrm{p}$. 484). A escolha de uma ou várias das opções estaria intimamente relacionada com os meios financeiros, técnicos e humanos disponíveis para cada projecto. Com excepção dos complexos de águas provenientes de nascentes termais, a grande maioria dos restantes edifícios balneares possuía reservatórios, que permitiriam não só a regulação e manutenção da pressão de água necessária ao fornecimento de água às diversas valências dos edifícios, mas também a sua manutenção em funcionamento em momento de menor disponibilidade de água, ainda que apenas por breves períodos. Dependendo das características de cada um, os usos dados a esta água podiam variar, sendo esta distribuída, por meio de um sistema de condução interna, pelos tanques e fontaná- rios de água fria, ou encaminhadas para os circuitos de calefacção. (Manderscheid 2000, p. 490-501).

A cada ciclo de renovação da água correspondia um avultado fluxo de efluentes a ser eliminado, sendo, todavia, comum a reutilização destas águas, a par das águas pluviais depositadas no interior dos edifícios, para tarefas de limpeza dos próprios espaços ou evacuação de resíduos fisiológicos e de outros detritos acumulados nos sistemas de escoamento internos do edifício (Manderscheid 2000, p. 503505). Esta última etapa do ciclo da água, à semelhança da primeira, colocava condicionantes à escolha de uma localização para o edifício, devido à necessidade de precaver o destino a dar a estes resíduos, em virtude da topografia e densidade urbanística envolvente bem como os recursos financeiros, técnicos e humanos disponíveis.

Apesar de fundamentais ao funcionamento de um edifício termal, os elementos hidráulicos responsáveis pelo escoamento das águas têm recebido uma atenção francamente menor do que os sistemas de adução, resultando em lacunas no seu conhecimento (Acero 2018a, p.38-39).

\section{OS EDIFÍCIOS TERMAIS DE MIROBRIGA - CAPTAÇÃO E UTILIZAÇÃO DE ÁGUA}

A construção do primeiro edifício termal público, as Termas Este, remontará aos finais do século I d.C / 120 d.C. (Biers 1988, p. 108-115). A sua implantação num fundo de um vale ao redor do qual têm vindo a ser identificadas algumas nascentes (Biers 1988, p.8), parece ter sido a única localização, no perímetro conhecido da cidade, que permitia a captação de água em volume suficiente. Aquando da construção das Termas Oeste, possivelmente algumas décadas mais tarde (Biers 1988, p. 108-115), aplicar-se-iam as mesmas condicionantes, pelo que o novo edifício foi justaposto ao já existente, utilizando águas das mesmas fontes (Felício 2019, p.18). (Figura 2)

Até ao momento, não obstante a menção, no século XVI, da existência de um aqueduto (Barata e Vale 2010, p. 12-13), não foi encontrado qualquer vestígio de um conduto para captação e transporte de águas desde longas distâncias, pelo que esta referência poderá, ou ser fruto de uma interpretação errada de uma estrutura parcialmente visível à data (Felício 2019, p.17), ou ser relativa a um aqueduto de menor dimensão, hoje desaparecido, que fizesse a ligação entre as fontes locais e os edifícios termais. 
Com efeito, associado às Termas Este, foi identificado um reservatório em alvenaria, revestido a opus signinum, situado a imediatamente a sul do edifício termal e apenas parcialmente escavado, que seria responsável pela manutenção do caudal e pressão pretendidos (Reis 2014, p. 213-215). A sua volumetria não é conhecida, uma vez que a sua escavação não foi concluída. No entanto, em 1998 (Barata 1999) e 2004 (Quaresma 2014), foram detectadas diversas canalizações de adução de água, pelo que este aprovisionaria água de diversas fontes. Esta hipótese é compatível com a dimensão relativamente pequena das nascentes identificadas até ao momento na área. Para além desta estrutura, foi ainda proposta a existência de um segundo reservatório na área (Felício 2019, p. 19) que, pela localização, deverá pertencer ao sistema de abastecimento das Termas Oeste. A ligação entre estas estruturas e o sistema de adução de água de cada um dos edifícios não está, ainda, totalmente esclarecida. Contudo, é expectável que esta consistisse numa canalização com alguma envergadura, possivelmente um pequeno aqueduto, tal como a existência de uma torre em alvenaria, localizada entre o possível segundo reservatório e os praefurnia das Termas Oeste, parece sugerir.

O volume de água necessário para o funcionamento das Termas Este foi calculado em aproximadamente $33,15 \mathrm{~m}^{3}$ de água, excluindo o volume do tanque localizado no tepidarium, cujo estado de conservação não permitiu o cálculo volumétrico. Para as Termas Oeste o volume calculado foi de aproximadamente $39,97 \mathrm{~m}^{3}$ (Reis 2014, p. 213), valores correspondentes a cada ciclo de renovação das águas, cuja regularidade desconhecemos.

A cada ciclo de renovação seria aproximadamente este o volume necessário e ao qual o sistema de captação e armazenamento de água teria de dar resposta. Contudo, uma vez que a escavação dos reservatórios não se encontra concluída, não é possível compreender se o sistema estaria bem dimensionado ou qual a sua eficiência.

\section{O SISTEMA DE ESCOAMENTO E SUA EVOLUÇÃO}

A implantação dos edifícios e concepção do seu sistema de escoamento aproveitou a existência de uma ribeira sazonal no vale, consistindo, assim, uma solução simples e de baixo custo para o escoamento dos efluentes procedentes dos diversos tanques, bem como os resíduos fisiológicos provenientes das latrinas, uma vez que o seu leito actuaria como canal de transporte para fora do perímetro urbanizado, mesmo em períodos em que a ribeira estivesse seca. (Figura 2)

A origem dessa linha de água encontra-se na própria topografia da cidade de Mirobriga, que favorece o escoamento de águas pluviais ao longo das encostas e vales das suas diversas colinas, criando três grandes zonas de confluência de águas, duas das quais se unem, acabando por formar uma ribeira sazonal em períodos de maior pluviosidade.

Esta dinâmica, apesar de favorecer o escoamento dos efluentes produzidos pelos edifícios termais, expunha-os a uma enorme pressão hídrica, proveniente das encostas, durante os períodos de pluviosidade intensa, desvantagem que desconhecemos se terá sido equacionada aquando da projecção do primeiro edifício.

\subsection{Termas Este}

O edifício encontra-se construído no sopé da vertente sul da colina do forum, a norte do leito da ribeira. Ao longo da sua vida útil, que, com base nos dados actualmente disponíveis, terá abarcado o período desde os finais do século I d.C. / 120 d.C. até meados do século III d.C. (Biers 1988, p. 108-115 e Apendix C p. 180-182), sofreu diversas reformulações, fruto não só de novas necessidades ao nível do circuito balnear, mas também das claras dificuldades ao nível da gestão dos caudais de águas pluviais que se concentravam no entorno do edifício.

\subsubsection{Primeira fase}

Na sua fase original, o edifício seria composto apenas pelas Salas 13 a 17 e pela zona de serviço. Nesta fase, as Salas 15 e 16, tepidarium e caldarium, respectivamente, teriam menores dimensões. Sondagens efectuadas na Sala 12 revelaram que esta era resultado de uma ampliação, e que anteriormente o porticus se prolongava para esta área (Biers 1988, p. 289). Na altura, devido à relação estratigráfica entre o muro estilóbato identificado e o corpo principal do edifício, não foi excluída a hipótese de o pátio porticado ser também uma adição ao edifício, sendo a sua construção designada como Fase $1 \mathrm{~b}$ (Biers 1988, p. 108-115). Assim, os dados cronológicos recolhidos, referentes à construção do muro estilóbato, permitem apenas datar o porticus.

Aquando da construção do edifício, a ribeira sazo- 
nal foi parcialmente canalizada passando a correr sob o mesmo, através da cloaca designada por $\mathrm{C}_{35}$, uma estrutura abobadada construída em alvenaria de pedra calcária com aproximadamente im de largura (Felício 2019, p.70). Esta canalização actuaria como elemento base do sistema de escoamento do edifício termal aproveitando o caudal natural da ribeira para conduzir estes resíduos para longe da área urbanizada. (Figura 2-A)

A localização do tanque original do caldarium é-nos dada por aquela que seria a sua canalização de escoamento, na parede sul da Sala 16, que escoaria para a cloaca C35. (Felício 2019, p. 70). Já o tanque do frigidarium aparenta escoar directamente para o leito da ribeira, por meio de um sistema de canalizações de média dimensão identificadas a este do edifício (Barata e Tiago 2003), não utilizando a $\mathrm{C}_{35}$. As fotografias da intervenção de 2003 sugerem ainda a existência de uma canalização proveniente da zona dos praefurnia, não tendo, porém, a sua existência sido apontada no relatório. A confirmar-se a sua existência, devemos estar perante uma estrutura análoga ao conjunto identificado nos praefurnia das Termas Oeste, possivelmente relacionado com a limpeza dos hypocausta. (Figura 3)

Aos efluentes gerados no edifício somar-se-iam as águas pluviais que se acumulavam no porticus e que, embora não subsistam vestígios, poderiam ter sido escoados por meio de um sumidouro para a cloaca $\mathrm{C}_{35}$.

Nesta fase, a zona a oeste do edifício termal, a montante da ribeira, poderia estar consolidada por diques ou muros de contenção/desvio de águas, de forma a facilitar a sua condução para o interior da cloaca (Felício 2019, p. 70-71). No entanto, a terem existido, estas estruturas terão sido destruídas aquando da construção das Termas Oeste.

Em 1988 foi proposto que a $\mathrm{C}_{35}$ teria tido originalmente uma extensão maior, ligando-se à C25, e que a construção deste edifício termal teria cortado essa canalização original, unindo os dois troços sobrantes com o seu próprio sistema de escoamento (Biers 1988, p.75-79). Contudo, esta hipótese não dispõe, a nosso ver, de indícios suficientes, uma vez que a entrada da $\mathrm{C}_{35}$ não apresenta indícios evidentes de corte, além disso, a relação entre a C25 e as Termas Oeste aponta para que esta seja, pelo menos, contemporânea à construção deste edifício.
4.1.2. Fases intermédias sem cronologia atribuída A construção da Sala 10, uma latrina, foi anteriormente considerada como Fase $2 \mathrm{c}$ (Biers 1988, p.289) com base na análise da sobreposição de unidades murárias, que indicam que esta não faria parte da fase primordial do edifício. A escavação do interior da sala apenas revelou dados relativos ao seu abandono, não sendo impossível que a sala tenha sido construída antes da datação atribuída à $2^{\underline{a}}$ fase, pelo que se optou por designá-la como Fase ic (Felício 2019, 71-72) A escolha do local para a sua construção ter-se-á prendido pela proximidade do caldarium, reutilizando as águas como descarga para a latrina, adaptando a canalização de escoamento do caldarium para o efeito; e pela proximidade da cloaca $\mathrm{C}_{35}$, que passa directamente sob a Sala 1o. Este espaço, com capacidade para 9 utilizadores em simultâneo (Felício 2019, p. 118-121), apresentava, assim, um funcionamento híbrido combinando, com base nos atributos definidos por Alain Bouet (2009 p. 41-44 e 47-49), características das latrinas de esgoto sob dois lados e das latrinas em poço/avaloir (Felício 2019, p 93-94).

Nesta fase as águas pluviais acumuladas no porticus seriam escoadas para o canal principal da latrina através de uma canalização localizada no paramento oeste da Sala 1o, actualmente bastante degradada.

Num momento indeterminado foi também construída uma canalização, na Sala 14, ao longo da borda do tanque, com origem no paramento este da Sala 13, junto ao pavimento, e que se unia ao sistema de escoamento do frigidarium. A adição desta estrutura foi interpretada como uma resposta a necessidades de limpeza que, presumivelmente, não haviam sido precavidas. Neste ambiente, a entrada e saída no tanque, mais ou menos frequente, aliada à circulação dos utentes para o interior ou exterior da sala, facilmente deixaria o pavimento bastante sujo, pelo que a existência de um ponto de escoamento facilitaria a eliminação das águas utilizadas na limpeza e lavagem do pavimento.

\subsubsection{Segunda Fase}

Esta fase caracteriza-se pela construção da Sala 12, interpretada como apodyterium. Esta fase data de, pelo menos, $155 / 158$ d.C., tendo sido encontrado um numisma de Antoninus Pius na preparação para a colocação do piso em opus signinum da sala (Biers 1988, p. 86 e 111 e Apendix C p. 183). Aqui poderá ter sido igualmente adicionada a Sala 8 , anteriormente 
inscrita numa Fase $2 b$ (Biers 1988, p.289). Consideramos que ambos espaços pertençam a uma mesma reformulação uma vez que a construção de uma canalização com origem na Sala 8 acarretaria um corte no pavimento da Sala 12, do qual não existem evidências; e que o seu ponto de escoamento desta canalização, localizado na parede sul da Sala 12, aparenta ser contemporâneo da construção deste paramento. A existência deste elemento de escoamento, associável às necessidades de limpeza do espaço, autoriza a interpretação da Sala 8 como possível unctorium/destrictarium, onde actividades relacionadas com a aplicação de óleos e sua remoção, por meio de strigil $^{-}$es, implicaria uma limpeza frequente do pavimento (Felício 2019, p 72-73). A localização desta sala no lado oposto ao elemento central de escoamento do edifício não tornava fácil a construção de uma ligação directa à cloaca $\mathrm{C}_{35}$, acabando os efluentes por ser escoados para o pavimento do pátio, e posteriormente encaminhados por gravidade, do mesmo modo que as águas pluviais, para o canal principal da latrina.

A esta fase foi também associada a construção da estrutura $\mathrm{C}_{3} 8$, localizada ao longo do lado norte do edifício termal, e que se adossa à Sala 8. Esta consiste numa segunda parede, paralela ao limite da Sala 12, distanciada em média o,6om desta. No espaço entre ambas, e à cota de conservação do muro interior, foi identificado um revestimento em opus signinum, dotado de meia-cana, acompanhado todo o comprimento do lado norte do edifício, adossando-se, no seu topo norte, à parede da Sala 8.

As características da estrutura e respectiva localização levam-nos a crer que se trate de uma estrutura de impermeabilização, podendo ter-se tratado de uma estrutura de deflexão de águas pluviais, depositando-as no lado este do edifício, permitindo que se encaminhassem para o leito da ribeira; ou então de uma estrutura de paredes duplas, uma solução com vista a criar um espaço oco e diminuir a percolação de água e humidade para o seu interior (Felício 2019, p. 115-118), comummente adoptada em edifícios construídos contra pendentes e em ambientes de elevada humidade (Vitr. VII, 4,1; Giuliani 2006, p. 158, fig. 12).

Além desta estrutura, também a $\mathrm{C}_{5} \mathrm{O}$, adossada à Sala 8, poderá ser incluída nesta segunda fase. Esta estrutura consiste num embasamento em alvenaria, cujo topo em declive, revestido a opus signinum, deflecte a água e protege a base do muro, contra o qual foi construído, de infiltrações.
A adição destas estruturas, apesar de não consistirem em elementos do sistema de escoamento, revela-nos que o edifício seria atingindo por um caudal considerável de águas pluviais que, devido a um escoamento pouco eficiente, provocaria problemas de infiltração de águas ou humidade. Estes problemas poderão não ter sido equacionados à data da construção do edifício ou terem sido agravados devido a alguma transformação da sua envolvente, da qual pouco se conhece.

\subsubsection{Terceira Fase}

Esta fase caracteriza-se pela construção das absides actualmente existentes nas Salas 15 e 16, distinguíveis como uma nova fase, relativamente à construção da Sala 12, devido aos os seus níveis de fundação se situarem a uma cota mais baixa que os dessa sala, à qual a abside da Sala 15 se adossa (Biers 1988, p. 105). Esta reformulação anulou tanque original do caldarium e respectiva canalização de escoamento, criando dois novos que passaram a escoar directamente para o pavimento do pátio porticado, hipótese já apresentada por outros autores (Biers 1988, p.102; Reis 2014, p.199). Os efluentes dos tanques, à semelhança das águas pluviais e efluentes da Sala 8, fluiriam pelo pavimento até ao canal principal da latrina. Nesta fase foi também adicionado um tanque na Sala 15, tepidarium (Biers 1988, p. 105), não sendo o seu escoamento fácil de determinar, uma vez que a quase totalidade do nível de circulação da Sala 15 colapsou para o interior do hypocaustum. Foi proposto anteriormente que o espaço para a passagem de uma canalização, conformado por dois imbrices colocados um sobre o outro, localizado no exterior da parede desta abside, fosse a localização da sua canalização de escoamento (Reis 2014, p. 199). Contudo, a existência de uma estrutura idêntica na abside mais pequena do caldarium, localizada a uma cota superior à do escoamento do tanque e apontada como o provável ponto de adução de água ao mesmo, sugere que estrutura identificada na abside do tepidarium, por analogia, se destinasse igualmente à adução de água ao espaço (Felício 2019, p. 76). Com efeito, a identificação de uma canalização localizada no hypocaustum da Sala 15 imediatamente sob a localização do tanque, (Biers 1988, p. 98-99), leva-nos a crer que esta canalização estará relacionada com o escoamento do mesmo.

A existência de canalizações de escoamento no interior de hypocausta não é incomum, sendo, con- 
tudo, mais frequente nos praefurnia quando o escoamento dos tanques é feito através de testudines (Maréchal, 2017). Neste caso, uma vez que não conhecemos o percurso total desta canalização e não podemos garantir que fosse realmente a estrutura de escoamento do tanque da Sala 15, é difícil formular uma hipótese acerca do motivo pelo qual o escoamento deste tanque seria distinto dos restantes. Em todo o caso, a existência desta estrutura, no interior do hypocaustum, contribui a favor da existência de uma canalização proveniente da área de serviço, anteriormente mencionada.

Para além das alterações no circuito balnear, foi associada a esta fase a construção de uma barreira em tijolo, revestido de opus signinum, localizada junto da entrada do edifício termal $\left(\mathrm{C}_{3} 6\right)$, que teria a função de impedir a escorrência de águas pluviais para a entrada do edifício, desviando o fluxo para o interior do sistema de escoamento das Termas Oeste. Esta barreira consistiria, assim, numa protecção adicional, revelando a sua posterioridade em relação às reformas anteriores que não terão sido suficientes. Embora não possuamos quaisquer dados cronológicos precisos para a sua construção, esta terá, necessariamente, ocorrido após a construção das Termas Oeste.

A construção deste sistema de desvio de águas pluviais levanta ainda questões relativas à propriedade dos dois edifícios termais, uma vez que uma estrutura pertencente a um edifício atravessa tão contundentemente outro, sugerindo um proprietário comum, situação que é também sugerida pelo facto de a canalização basilar do sistema de escoamento das Termas Oeste escoar para a $\mathrm{C}_{35}$.

\subsubsection{Encerramento e abandono}

Apesar de a quase totalidade do edifício termal ter sido escavado num momento recuado, não havendo registo dos contextos que existiriam, foram identificados três contextos preservados, dois dos quais permitiram datar a obstrução da canalização da Sala 8 e do canal principal da latrina (Biers 1988, Apendix C p. 180-182). Estes apontam para a obstrução destas canalizações a partir de meados do século III d.C., não existindo materiais posteriores ao início do século IV d.C., sugerindo que o encerramento do edifício termal terá ocorrido um pouco antes, talvez na primeira metade do século III d.C., levando ao assoreamento do seu sistema de escoamento e saneamento. No caso do tanque do frigidarium, o con- texto aí identificado, apesar de não conter material datante significativo preservado (Biers 1988, Apendix C p. 192-195), sugere que o espaço, que à data já se deveria encontrar parcialmente em ruína, tenha sido utilizado como lixeira (Felício 2019, p. 78-79).

\subsection{Termas Oeste}

As sondagens efectuadas nos anos 1980 foram inconclusivas, permitindo apenas fixar a construção do edifício algures na primeira metade do século II d.C., não devendo a sua construção distar da das Termas Este mais do que algumas décadas (Biers 1988, p. 108-115). O seu aspecto actual é também resultado de algumas remodelações ao longo do tempo, embora os dados actualmente não permitam distinguir se todas terão ocorrido numa mesma altura e qual a sua cronologia. A este respeito, devemos referir que para o presente artigo apenas foram tidos em conta os elementos directamente relacionados com o sistema de escoamento do edifício.

\subsubsection{Fase original}

O edifício encontra-se justaposto ao muro ocidental das Termas Este, alçado partilhando por ambos os edifícios, e evidencia uma concepção, ao nível da gestão e escoamento de efluentes e águas pluviais, muito mais completa, quando comparada com a do edifício vizinho, demonstrando uma maturação no conhecimento do terreno e suas problemáticas no período que discorreu entre a construção dos dois edifícios termais. (Figura 2-C)

O seu sistema de escoamento tem por base uma cloaca que contorna o edifício ( $\mathrm{C}_{56}$ ), para a qual confluem todos os resíduos gerados no edifício. Esta situa-se sob um recinto impermeabilizado (Pátio Nordeste e um possível segundo pátio a este do edifício) que permite a recolha de águas pluviais e sua condução, por meio de diversos sumidouros, para o interior da cloaca C56 (Felício 2019, p.8o-87), criando um perímetro que afasta o edifício das vertentes do vale. (Figura 4)

Para além desta canalização foi criada uma outra, C25, com 0.85m de largura e uma altura de 1,40m, que provavelmente replicaria o traçado da antiga ribeira, agora soterrada pela urbanização do vale. O propósito deste elemento aparenta estar unicamente relacionado com a captação de águas pluviais de escorrência superficial que se acumulariam na base do pequeno vale a sul das Termas Oeste e que corresponde a uma das zonas naturais de confluên- 
cia de águas identificadas. Nesta fase é possível que estas águas fossem encaminhadas para o pátio que contorna o edifício termal, sendo depois escoadas para a cloaca $\mathrm{C}_{5} 6$.

O sistema que protegia o edifício da pressão provocada pelas águas pluviais contemplava ainda duas estruturas de impermeabilização por deflexão de águas $\left(\mathrm{C}_{51}\right.$ e $\left.\mathrm{C}_{52}\right)$ localizadas no canto norte, no exterior da Sala 3, entre as quais se situava um sumidouro. Este sistema, localizado precisamente na base de outra das zonas de confluência de águas, aliado à morfologia da própria via a Oeste do edifício, que apresentava uma nervura central, conduzindo as águas pluviais na direcção do sumidouro, captava a maioria destas águas, encaminhando-as para o sistema de escoamento.

Quanto aos elementos de escoamento em si, embora a totalidade do percurso da cloaca $\mathrm{C}_{5} 6$ não seja, actualmente, transitável, existindo troços não escavados e uma zona onde esta colapsou, é possível reconstituir o seu percurso em torno do edifício. Esta tem início no topo norte do edifício, junto à Sala 3, contornando o edifício pelo sul e desembocando no canal principal de uma latrina simples de esgoto sob dois lados localizada na Sala 9, onde foi estimada uma capacidade de 12 utilizadores em simultâneo (Felício 2019, p. 118-121). O canal da latrina escoa, por sua vez, para a cloaca $\mathrm{C}_{35}$, pertencente às Termas Este, seguindo posteriormente para o leito da ribeira, a jusante do complexo termal.

A C56 apresenta paredes em alvenaria de pedra, apresentando uma cobertura em abóbada, sendo o seu pavimento em tijolo. Percorre os lados Oeste, Sul e Este do edifício termal e apresenta uma altura de entre $0.80 \mathrm{~m}$ e $0.90 \mathrm{~m}$ e uma largura de $0.6 \mathrm{om}$ nos troços Este e Sul, e de $0.70 \mathrm{~m}$ no troço Oeste. As dimensões da cloaca permitem a circulação de um adulto no seu interior, rastejando, sendo assim possível proceder à sua manutenção, tendo sido identificados dois pontos de acesso ao sistema subterrâneo: $O$ primeiro (C33) localizado no corredor de acesso à latrina, que consiste numa abertura de $1.10 \mathrm{~m}$ por $1.12 \mathrm{~m}$; e um segundo localizado no Pátio Noroeste (C23) estrutura já anteriormente apontada como entrada para manutenção, devido à sua dimensão (o.6oxo.7om), (Biers 1988, p. 74). Ambos os pontos de entrada estariam cobertos, apresentando o do pátio uma moldura de meia-cana em opus signinum, que impediria a entrada de águas pluviais naquele ponto.

$\mathrm{Na}$ sua fase original, o edifício contaria apenas com dois tanques, um no caldarium e outro no frigidarium, sendo que o primeiro escoava para a $\mathrm{C}_{5} 6$, por meio de uma fistula, controlada por uma possível torneira localizada no Pátio Nordeste; e o segundo para o canal principal da latrina, por meio de uma canalização conformada em tijolo, embutida na alvenaria da parede e possivelmente vedada por uma tampa ou rolha.

Para além dos tanques e das águas pluviais, o sistema de escoamento original das Termas Oeste contemplava ainda canalizações associadas à limpeza e manutenção do espaço. Destas, duas estavam ligadas ao percurso balnear e três à área de serviço aos praefurnia.

As primeiras, localizadas nas Salas 1 e 4, encontram-se contruídas em alvenaria de tijolo, e foram associadas à limpeza dos pavimentos, sendo possível observar, em cada uma das salas, um declive que pende na direcção de cada uma destas canalizações: Uma localizada no localizada na base do canto este da Sala 4 (frigidarium) e que escoaria os efluentes resultantes da limpeza do pavimento para o canal principal da latrina; e outra localizada na Sala 1, interpretada como uma possível palestra interior, onde, a par da actividade física seriam realizadas actividades de unção e limpeza do corpo, pelo que a presença de um ponto de escoamento facilitaria a limpeza do espaço (Felício 2019, p. 82), Esta proposta encontra paralelo em edifícios como a chamada "Palestra dei Iuvenes", regio VIII.2.23, um espaço associado ao Complexo Termal do Sarno, em Pompeii, cujo pavimento está igualmente dotado de escoamento.

Já na sala de serviço aos praefurnia foram identificadas três canalizações, uma construída em tijolo, cuja cobertura seria, possivelmente em lajes de pedra e duas de menor dimensão escavadas directamente no substrato geológico (xisto) (Biers 1988, p. 116). Com base nos dados disponíveis, foi proposto que as três canalizações fizessem parte de um possível sistema de limpeza dos hypocausta, escoando águas e cinzas resultantes da sua lavagem (Felício 2019, p. 83). Estas estruturas encontram paralelo no edifício termal de Eburobrittium, tendo-se sugerido que pudessem ser responsáveis pelo escoamento de tanques (Reis 2014, p. 305-306)

\subsubsection{Remodelações}

Apesar de o edifício não ter sofrido reestruturações de vulto, existem algumas estruturas hidráulicas que terão sido adicionadas ao longo do seu período 
de funcionamento, muito embora não possamos, de momento, localizar ou ordenar cronologicamente algumas delas. Com efeito, a única estrutura para a qual possuímos um indicador cronológico relativo é a canalização localizada no corredor de acesso à latrina, que foi construída em simultâneo com a barreira $\mathrm{C}_{3} 6$, enquadrada na terceira fase das Termas Este. Inicialmente pensou-se que ambos os tanques da caldarium pertencessem ao projecto original (Biers 1988, p. 75-78), no entanto, as observações efectuadas no interior da cloaca $\mathrm{C}_{5} 6$ revelaram que esta foi cortada para construção do hypocaustum do tanque de menor dimensão, existindo também indícios de ter existido uma janela no paramento onde o tanque se situa actualmente (Felício 2019, p. 88). Na Sala 6, caldarium, foi adicionado um segundo tanque, de menor dimensão, $\mathrm{O}$ escoamento deste novo tanque seria feito por meio de uma fistula (Biers 1988, p. 69), que se encontra actualmente incessível devido ao colapso de parte da cloaca $\mathrm{C}_{56}$. A construção desta nova abside obrigou a uma reformulação no traçado desta cloaca, no interior da qual foi identificado o corte para a implantação do hypocaustum do novo tanque, bem como a abertura, a sul, de um novo troço que contorna a nova abside. Este troço apresenta uma cobertura de lintéis calcários, ao contrário da restante $\mathrm{C}_{5} 6$, que possui uma abóbada de canhão construída em placas de xisto. Infelizmente este troço encontra-se obstruído pelo colapso quer da sua cobertura, quer de parte do paramento da abside do caldarium. Esta adição provocou constrangimentos também na C25, cujo escoamento, possivelmente para o pavimento do pátio, se faria precisamente neste local, levando à necessidade de criar uma ligação entre esta e novo troço da $\mathrm{C}_{5} 6$.

A adição de um novo tanque no caldarium, levanta a possibilidade de o tanque mais pequeno do frigidarium ser também resultado desta reformulação do edifício, que teria, assim, recebido um incremento de capacidade com a adição de mais um tanque em cada uma das salas de banho (Felício 2019, p. 89). Esta hipótese que carece ainda de confirmação, uma vez que a $\mathrm{C}_{5} 6$ se encontra obstruída nesta zona, podendo o terminar da sua escavação vir a clarificar a relação estratigráfica entre a canalização de escoamento deste tanque e as estruturas que sabemos serem originais do edifício.

\subsubsection{Encerramento e abandono}

A falta de dados relativos à sua escavação, somada ao facto de as sondagens efectuadas no troço da $\mathrm{C}_{5} 6$ sob o Pátio Noroeste não terem encontrado qualquer material, datante ou não, no seu interior (Biers 1988, p. 73-75), não permitiram chegar a uma conclusão acerca do encerramento do edifício. No entanto, uma vez que o sistema de escoamento das Termas Oeste dependia da manutenção da $C_{35}$, pertencente às Termas Este, o edifício não teria meio de subsistir caso esta canalização se encontrasse obstruída, o que poderá ter acontecido a partir do encerramento desse edifício termal (Felício 2019, p. 89-90). É, todavia, possível que a manutenção da cloaca possa ter continuado a ser realizada pelos responsáveis pelas Termas Oeste após o encerrar do edifício vizinho, uma vez que o ponto de acesso para manutenção localizado junto à latrina permite também o acesso à C35. Contudo, os dados recolhidos nas Termas Este e na envolvente (Arthur 1983, p.81-83; Biers 1988, Apendix C p. 180-182 e 192-195; Felício 2019, p. 26-27), não obstante um possível restauro localizado do pavimento da ponte nessa cronologia (Quaresma 2014, p. 127) são consistentes com um cenário de degradação e abandono ou, pelo menos, negligência desta zona da cidade a partir de meados do século III d.C., sendo plausível que nesta cronologia, as Termas Oeste não se encontrassem igualmente em funcionamento. Com efeito, a recolha, em 1955, de elementos pétreos no Amb.2 do designado Edifício $\mathrm{C}$, num contexto enquadrável na primeira década do século IV d.C. (Arthur 1983, p. 83 e 99-102; Felício e Sousa 2019, p. 138-139), identificados à data, como possivelmente pertencentes às Termas Oeste (Arthur 1983, 96-97), aponta uma possível cronologia para a espoliação de elementos decorativos dos edifício, consistindo, assim, num terminus ante quem para o seu encerramento.

\section{MANUTENÇÃO, SANEAMENTO E PAISAGEM URBANA}

A contaminação ambiental provocada pelas cidades antigas não é novidade, sendo já merecedora da crítica de algumas das personalidades da época, que se queixavam da sujidade e odores fétidos que algumas cidades, em particular as de maior dimensão, apresentavam, (Acero 2018a, p. 70-76).

Se, por um lado, estes efeitos seriam particularmente notórios nas grandes metrópoles, devemos, por outro, salientar que por menor que um aglomerado urbano possa ter sido, algumas das actividades 
e valências inerentes a estes núcleos populacionais, como sejam a convivência próxima de pessoas, a laboração de oficinas manufactureiras, mercados de animais ou, no que ao presente artigo se refere, os edifícios termais, teriam, sem dúvida, um importante papel enquanto focos de poluição.

Contudo, se actividades tidas como poluentes ou perigosas como as figlinae, oficinas, metalúrgicas, vidreiras e de preparados piscícolas ou mesmo os espaços dedicados aos fora boaria eram, geralmente, relegados aos espaços extra-urbanos (Acero Pérez 2018, p.85), os espaços termais encontravam-se, de uma forma geral, nas zonas centrais das mesmas. Para além das questões relacionadas com gestão florestal, suscitadas pelo consumo de lenha para alimentar os sistemas de calefacção dos edifícios termais, e que extravasam o âmbito do presente artigo, o dia-a-dia de um edifício termal tinha diversas implicações ambientais, nomeadamente ao nível do fumo proveniente dos praefurnia e dos efluentes gerados.

No seu interior, factores como a humidade e temperatura elevadas; a realização de actividades físicas, motivando a transpiração; seguida da utilização de óleos e sua deposição no pavimento; a entrada e saída de várias pessoas nos tanques e circulação entre vários os ambientes; bem como a preparação e consumo de alimentos nos estabelecimentos concorriam para a criação de uma atmosfera pouco limpa. Os testemunhos que nos chegaram acerca destes espaços, apesar de enaltecerem os benefícios e comodidades desta actividade de lazer, transmitem também a volatilidade com que os mesmo se degradariam, levando, por exemplo, ao surgimento de baratas (Plinius apud Jansen 2011, p. 159). À dinâmica do circuito balnear, somar-se-ia o funcionamento das latrinas, quase omnipresentes nestes complexos, onde a utilização comunitária do espaço, aliada a uma acumulação de resíduos fisiológicos nos canais sob os assentos, que muitas vezes apenas seriam escoados aquando de um ciclo de renovação de água nos tanques do complexo, criaria um ambiente muito pouco higiénico, pelo menos na acepção moderna do termo (Jansen 2011, p. 159-161).

Seria comum a gestão e exploração de um edifício termal estar concessionada a um Conductor Balnei, por meio de um contrato, após o terminus do qual o edifício e todo o equipamento a ele pertencente deveria ser entregue em bom estado. Durante a sua exploração, o conductor deveria manter o edifício a funcionar correctamente e proceder à limpeza regular das caldeiras, sendo-lhe cobrada uma indeminização por períodos de não funcionamento. (Encarnação 1984, p. 204-211).

Embora não sejam especificados os motivos pelos quais este não funcionaria correctamente e qual o equipamento a ser entregue em boas condições, o sistema de escoamento, sendo um dos aspectos fulcrais, constaria, certamente, na lista. O mesmo se aplicaria ao hypocaustum, sendo possível que a manutenção regular das caldeiras englobasse a totalidade do sistema de calefacção, podendo as estruturas de escoamento identificadas nos praefurnia de ambos os edifícios consistir um testemunho da limpeza ou lavagem dos resíduos de combustão.

A limpeza das diversas salas, embora não seja explicitamente mencionada, provavelmente estaria implícita na referência à conservação das condições de funcionamento do edifício, que supomos terem em consideração uma utilização minimamente agradável do espaço. Com efeito, a existência de estruturas de escoamento em ambientes associados à prática de actividade física e ao ritual de aplicação e remoção de óleos relacionado com esta, denuncia a realização de uma limpeza profusa do espaço (Felício 2019, p. 135-136), constituindo os únicos vestígios tangíveis de alguma regularidade na limpeza, sem a qual a qualidade do ambiente se degradaria rapidamente. Os efluentes gerados pelas actividades de limpeza e mudanças de água dos tanques teriam, numa boa parte dos casos, como destino a rede de cloacas das cidades, longe da vista e do olfacto, da maioria dos seus habitantes. Todavia, o mesmo não se terá passado em Mirobriga, onde, como vimos, a totalidade dos efluentes de ambos os edifícios termais era depositada no leito da ribeira sazonal, numa localização relativamente central da cidade, e imediatamente a montante de uma das vias acesso à mesma, o que terá, certamente, criado um ambiente algo desagradável, influenciando a paisagem urbana e sua vivência.

\section{CONSIDERAÇÕES FINAIS}

A localização da cidade, herdada de um antigo povoado indígena, é caracterizada pela existência diversas colinas, levando a que alguns dos edifícios fossem construídos a meia encosta ou mesmo no fundo de vales. Muitos dos eixos viários aproveitaram o declive natural das vertentes, tendo tomado o lugar de um sistema subterrâneo de escoamento, 
que nunca viria a ser construído, uma vez que consistiam numa forma simples de escoar as águas pluviais, e outros resíduos, dos vários pontos da cidade (Felício 2019, p. 20-27)

A construção dos edifícios termais na única localização conhecida que permitia a captação e adução de água necessária para o seu funcionamento, tirou também partido desta dinâmica natural de escoamento, tornando a ribeira sazonal e respectivo leito num dos principais agentes para o transporte das águas residuais daí provenientes.

Contudo, se em momentos de pluviosidade intensa, o caudal gerado era suficiente não só para transportar os resíduos, mas também para trazer problemas aos edifícios devido ao excesso de água e humidade; o mesmo poderia não ser o caso em períodos estivos. A escassez de chuva, e consequente diminuição dos caudais das nascentes, poderia causar disrupções no aprovisionamento de água aos edifícios; mas os seus efeitos far-se-iam sentir sobretudo ao nível do escoamento dos resíduos fisiológicos gerados nas latrinas, que em períodos de pouca ou nenhuma pluviosidade dependeriam apenas da renovação de água nos tanques para o seu transporte, o que poderá ter provocado a acumulação de resíduos no interior do próprio sistema de escoamento e no leito da ribeira. Não será demais destacar o impacto negativo que períodos de temperatura elevada aliados a uma acumulação de resíduos fisiológicos e outros efluentes teria na qualidade ambiental da zona, atravessada por uma importante via que ligaria a cidade ao circus e nas proximidades da qual existe, pelo menos, um edifício habitacional (Casa Periquito).

Dada a importância que este pequeno curso de água tinha para o bom funcionamento dos edifícios termais, é possível que nestes períodos algum tipo de acção de manutenção suplementar tenha ocorrido, sendo espectável que este fosse alvo de limpeza com alguma regularidade, nomeadamente da vegetação que aí crescia, mas também ao nível dos detritos acumulados, numa lógica talvez semelhante à da actuação dos foricarii ou stercorarii (Acero 2018, p. 74-75). Apesar das condicionantes impostas pelo terreno, os edifícios termais de Mirobriga procuraram, desde a concepção das Termas Este, adaptar-se e tirar partido das mesmas. Contudo, é notória uma evolução no conhecimento da forma como a topografia influenciava a dinâmica hídrica do local, materializada no planeamento cuidado do sistema de escoamento das Termas Oeste.
Esta evolução, que desconhecemos se se deveu a uma aprendizagem empírica ou à contratação de equipas mais especializadas aquando da construção do segundo edifício termal e reformulação do primeiro, legou-nos uma série de estruturas que nos permitem compreender quais as preocupações que a manutenção com a limpeza e salubridade mas também estabilidade destes edifícios acarretava, contribuindo para o conhecimento e para uma aproximação mais tangível àquele que seria o ambiente, vivência $\mathrm{e}$ realidade cultural destes espaços de lazer.

\section{BIBLIOGRAFIA}

ACERO PÉREZ, J. (2018a) - La gestión de los resíduos en Augusta Emerita (Mérida, España) Siglos I a.C. - VII d.C.Anejos del Archivo Español de Arqueología. LXXXII. CSIC - Instituto de Arqueología de Mérida. Mérida.

ACERO PÉREZ, J. (2018b) - Agua para el baño. Abastecimiento, uso y evacuación hídrica en las termas públicas de Hispania. In NOGUERA CELDRÁN, J.M.; GARCÍA-ENTERO, V. e PAVÍA PAGE, M. (eds.) Pre-Actas del Congreso internacional Termas públicas de Hispania (Murcia-Cartagena, 19-21 de abril de 2018). p.27-29.

ALMEIDA, F. (1964) - Ruínas de Miróbriga dos Célticos (Santiago do Cacém), Setúbal: Junta Distrital de Setúbal.

ARTHUR, M. L. C. (1983) - Merobriga. Santiago do Cacém (Portugal). In Caesaraugusta. 57-8, pp. 51-109.

BARATA, M. F. (1999) - Trabalhos arqueológicos na ponte romana de Miróbriga. Vipasca, 8. Aljustrel, pp. 67-72.

BARATA, M. F.; TIAGO, J. R. (2003) - Intervenção Arqueológica - exterior do muro limite das Termas Este. Relatório de escavação entregue à DGPC.

BARATA, M. F.; VALE, F. (2010) - Mirobriga o Tempo ao longo do Tempo. Catálogo da exposição decorrida no Museu Municipal de Santiago do Cacém, Museu de Arqueologia e Etnologia do Distrito de Setúbal e no Centro Interpretativo de Mirobriga. Câmara Municipal de Santiago do Cacém.

BIERS, W. R. (Ed.) (1988) - Mirobriga. Investigations at an Iron Age and Roman site in southern Portugal by the University of Missouri-Columbia, 1981-1986. BAR - International Series 451. Oxford.

BOUET, A. (2009) - Les Latrines dans les Provinces Gauloises, Germaniques et Alpines. Supplément à GALLIA 59. CNRS Éditions, Paris.

ENCARNAÇÃO, J. D' (1984) - Inscrições romanas do Conventus Pacensis. Coimbra: Faculdade de Letras de Coimbra. Instituto de Arqueologia.

FELÍCIO, C. (2019) - Gestão de Resíduos em Mirobriga - O Sistema de Saneamento (séculos I-IV d.C.). Dissertação de Mestrado em Arqueologia apresentada à Faculdade de Ciências Sociais e Humanas da Universidade Nova de Lisboa. 
FELÍCIO, C.; SOUSA, F. (2019) - Dois amuletos em osso de Mirobriga - Evidências do culto de Magna Mater? In OPHIUSSA $\mathrm{n}^{\circ}$ 3. UNIARQ. Faculdade de Letras da Universidade de Lisboa. pp. 133-143.

GIULIANI, C. F. (2006)-L'edilizia nell'antichità 2 $2^{\underline{a}}$ Edizione. Collana Manuali Universitari. Carocci.

JANSEN, G. C. M. (2011) - Toilets and Health. In JANSEN, G. C.M.; KOLOSKI-OSTROW, A. O.; MOORMAN, E. M. (Ed.) - Roman Toilets: Their Archaeology and Cultural History. BABESCH Annual Papers on Mediterranean Archaeology Supplement 19. pp. 157-164.

MANDERSCHEID, H. (200o) - The Water Management of Greek and Roman Baths. In Handbook of Ancient Water Technology. Brill. Leidein. pp. 467-535.

MARÉCHAL, S. (2017) - A note on the drainage of pools in Roman baths. In BABESCH - Annual Papers on Mediterranean Archaeology 92. pp. 179-186.
QUARESMA, J. C. (2014) - Escavações de 2004 e 2005 na área da ponte de Chãos Salgados (Mirobriga?): estratigrafia, arquitectura e materiais de um sector público da cidade romana. In Musa, nº 4. pp. 125-156.

REIS, M. P. (2014) - DE LVSITANIAE VRBIVM BALNEIS. Estudo sobre as termas e balneários das cidades da Lusitânia. Tese de Doutoramento apresentada à Faculdade de Letras da Universidade de Coimbra.

SILVA, J. G. C. (1944) - Apontamentos e considerações sobre as pesquisas arqueológicas realizadas desde 1922 nos concelhos de S. Tiago-de-Cacém, Sines e Odemira. In Arquivo de Beja nº̄1, pp. 226-31.

TEICHNER, Félix (2018) - Einleitende Bemerkungen zur Fundstelle. In Félix Teichner (Ed.). Mirobriga. Eine Stadt im fernen Westen des Imperium Romanum. Marburg. pp. 9-18.

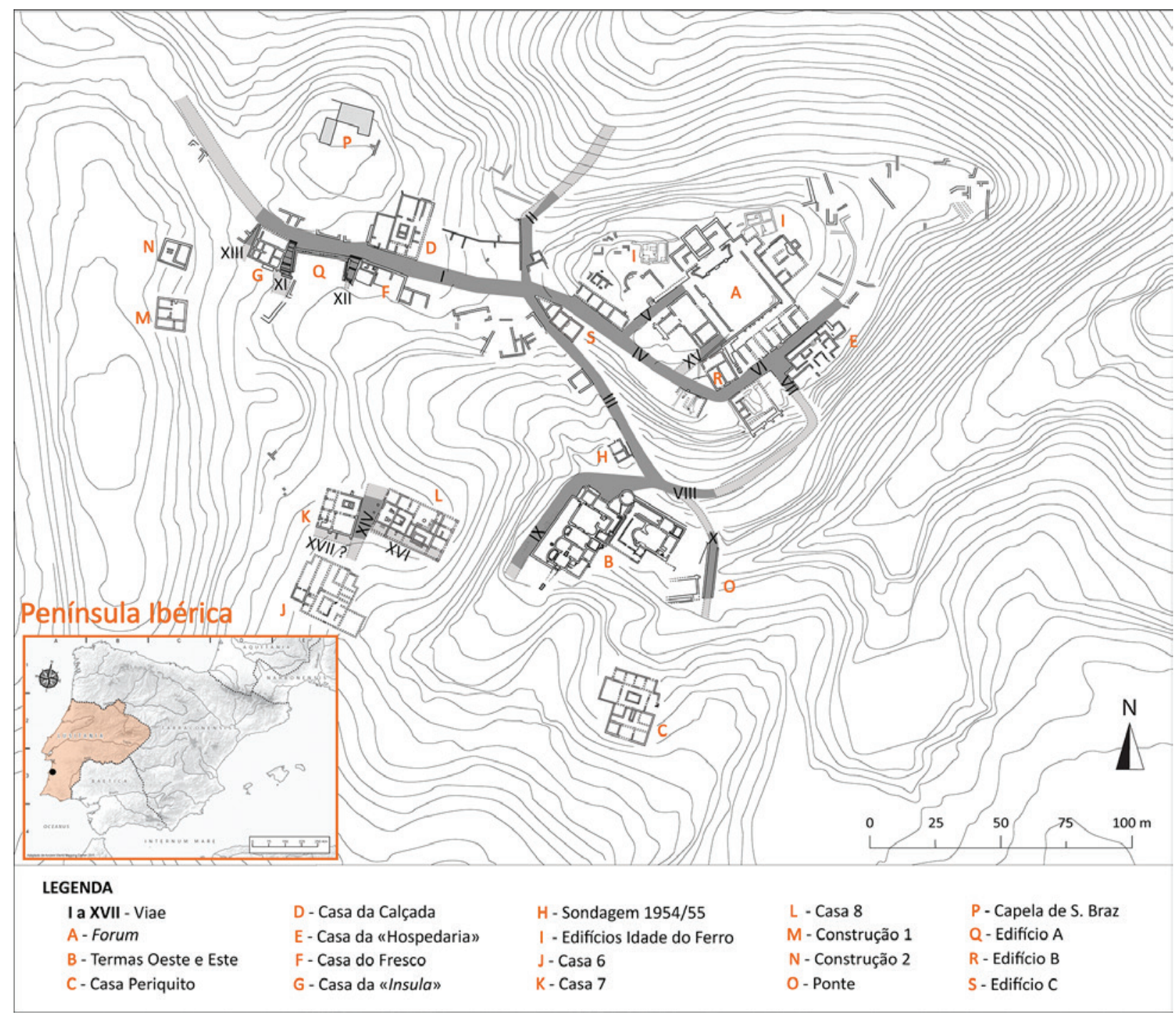

Figura 1 - Área urbana conhecida em Mirobriga. 

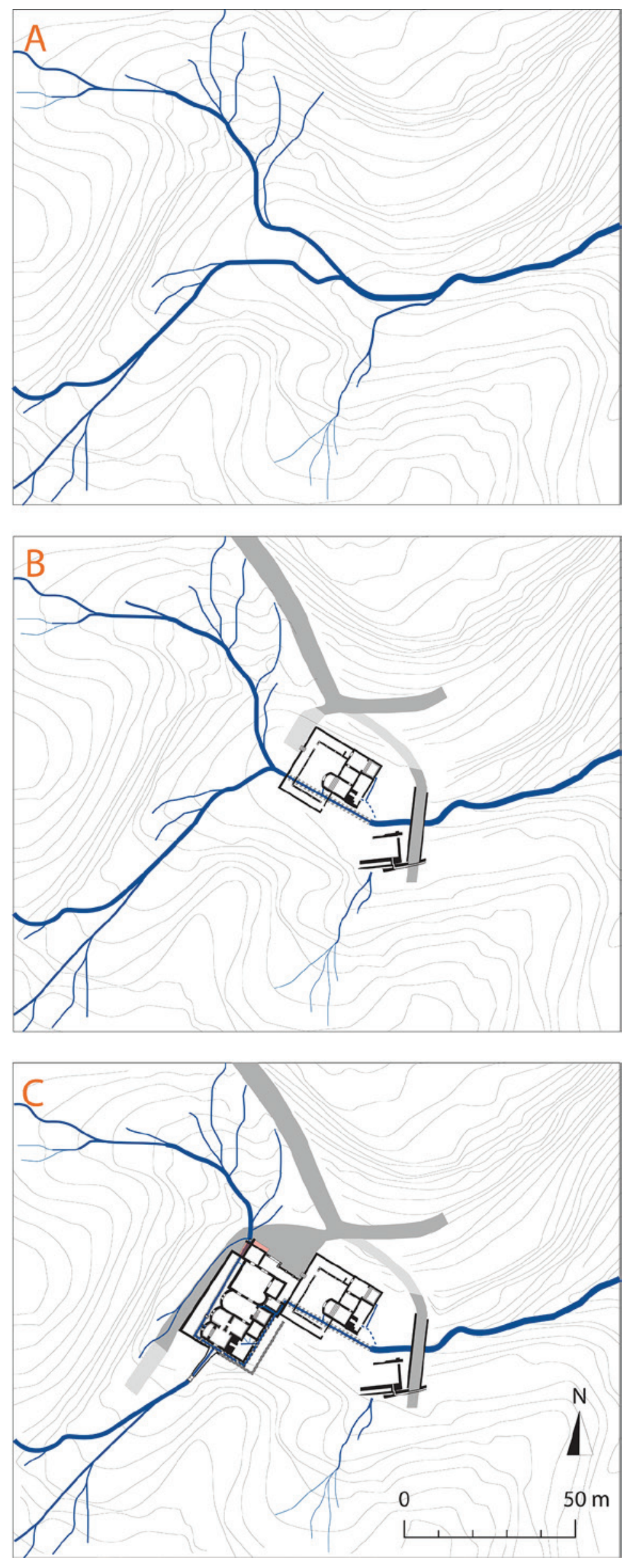

Figura 2 - Implantação dos edifícios termais e evolução das zonas de confluência de águas. (Linhas de água adaptadas de Teichner 2018, p.11) 

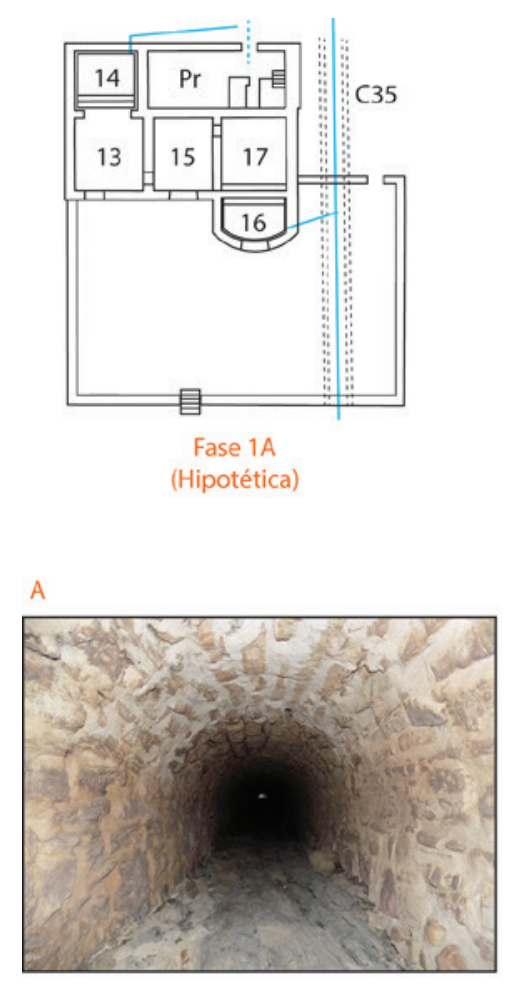

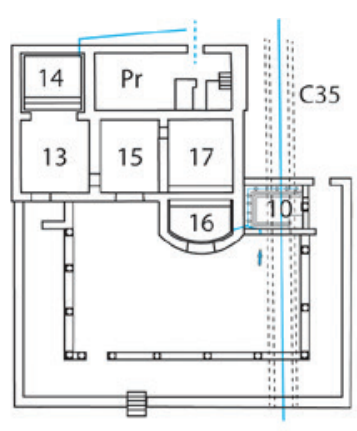

Fase $1 \mathrm{C}$

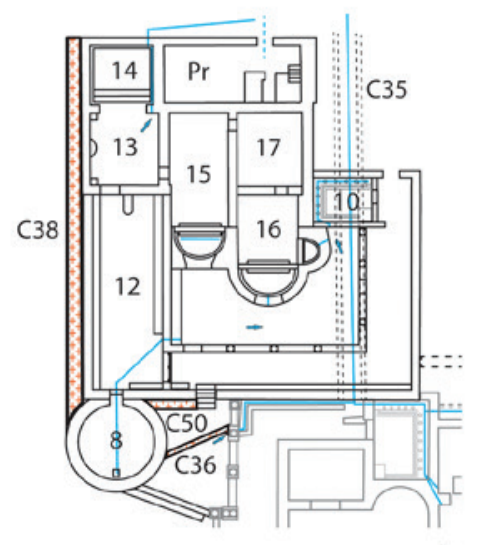

Fase 3

Figura 3 - Evolução do sistema de escoamento das Termas Este. A: Interior da cloaca C35.
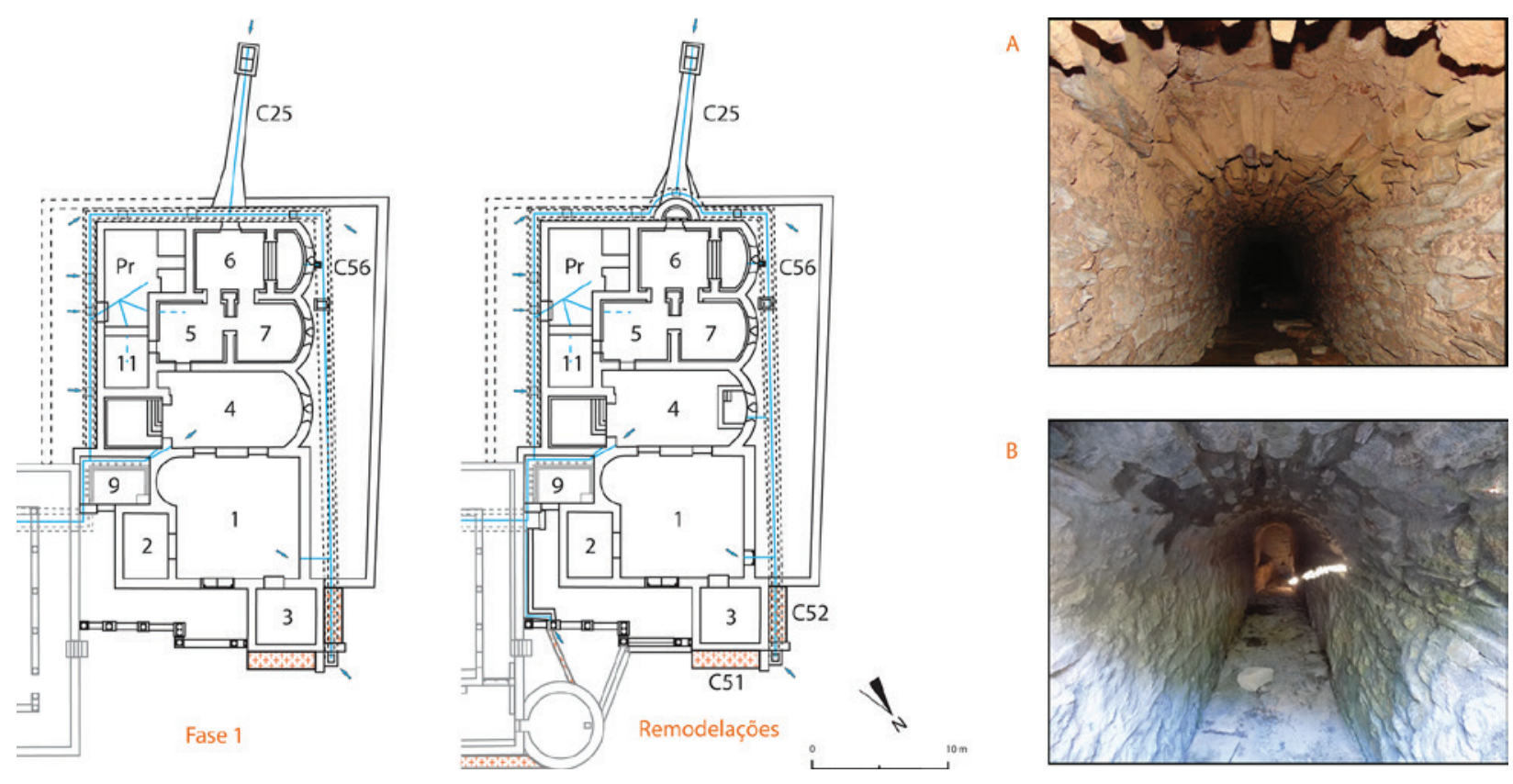

Figura 4 - Evolução do sistema de escoamento das Termas Oeste. A: interior do troço este da cloaca C56. B: Interior da cloaca C25. 


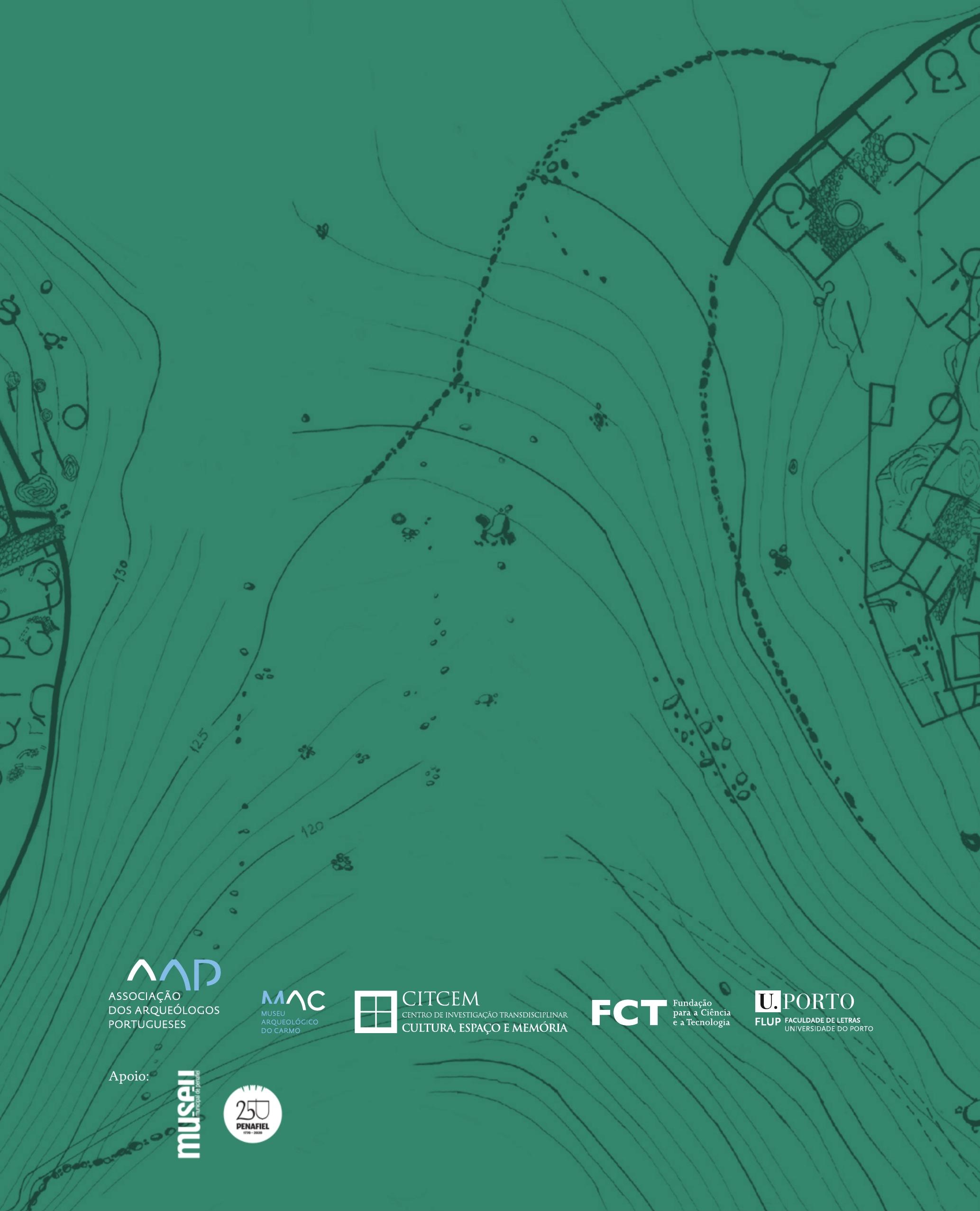

